\title{
THE STATE OF EXCEPTION IN THE GREEK CONSTITUTION:THE RESILIENCE OF THE GREEK CONSTITUTION DURING THE COVID-19 PANDEMIC ${ }^{1}$
}

DOI:10.47743/rdc-2021-1-0002

Evripidis STYLIANIDIS

Law School, European University Cyprus

\section{Abstract}

The state of exception is provided for in constitutions in response to emergency situations. The resilience of constitutions is tested in such situations, which are marked by the concentration of power in the executive and limitations in the exercise of fundamental rights. Although the Greek Constitution allows for the declaration of a state of siege, this does not include the case of a public health crisis. Nevertheless, particular constitutional provisions form an emergency mechanism, which proved to be effective against the COVID-19 pandemic and in accordance with democracy and the rule of law.

Keywords: resilience, COVID-19 pandemic, Greek Constitution, emergency mechanism

\section{Introduction}

The Greek Constitution is the dense institutional expression of the civilization's value system, which was democratically legitimized by a strong parliamentary majority determined by the people in elections that took place between two Parliaments, the Proposing and the Revising Parliament ${ }^{2}$.

The values, rights, democratic norms and institutions protected by the Constitution are deeply rooted. They are the pillars of stability of the Hellenic Republic and its legal civilization, the protective shield of the nation's cultural identity against an unpredictable globalization that promotes the cloning of civilizations, and thus cannot and should not be revised with the speed and ease of ordinary legislation ${ }^{3}$.

\footnotetext{
${ }^{1}$ Presented at the Annual Round Table - Romanian Association of Constitutional Law, 22 ${ }^{\text {nd }}$ Edition, 1-2 Oct. 2021.

2 E. Venizelos (2021), Constitutional Law Lessons. Sakkoulas, p. 31 (in Greek); E. Venizelos (2003), The Future of Democracy and the Resilience of the Constitution. Polis, pp. 113, 159 (in Greek).

${ }^{3}$ A. Pantelis (2020), Constitutional Law Handbook. Nomiki Vivliothiki, p. 91 (in Greek); E. Stylianidis (1995), Grundrechte und Gesetzesvorbehalt in der griechischen Verfassung und im Grundgesetz der Bundesrepublik Deutschland. Hamburg.
} 


\section{Evripidis STYNIALIDIS}

The Greek Constitution is strict regarding its revision procedure in order to withstand the test of time ${ }^{4}$, but is also open in order to adapt to developments, so as to avoid the crushing of the institutional framework ${ }^{5}$. The ordinary legislator is constitutionally mandated to follow the technological, political, social and economic developments with the greatest possible speed, to deal with the moral dilemmas that arise, and to establish new rights, while protecting the timeless core of values enshrined in the Charter of the country.

The Constitution itself allows for flexibility and adaptability through two channels, which absorb the shocks of unforeseen changes in international and European economic, social and political reality ${ }^{6}$. These channels over the last decade and during the two crises that Greece has gone through, the economic crisis on the one hand (2010-2018) and the health crisis on the other (2020 to date), have contributed in responding to both of them:

a) The informal change of meaning of constitutional provisions through the case law, which leads to a balanced and sensible compensation for the restriction of constitutional rights, especially social rights, when public interest goals defined by the Government are served. In this way, the case law motivates the legislature and the Government, but always on the basis of the principle of proportionality.

b) The procedural flexibility of the Constitution. To begin with, this is manifested in article 28 par. 2 and 3 of the Constitution, as well as in the relevant interpretative clause added during the 2001 Revision, which allows for the incorporation of international treaties to domestic law and the harmonization of the Greek legal order with the European. Most importantly, the Constitution contains provisions allowing for the introduction of exceptional legislative measures in case of extremely urgent and unforeseen circumstances ${ }^{7}$.

Specifically, the state of exception includes a set of specific measures adopted either in the event of a serious threat to national security and to the democratic regime, or to prevent, mitigate or eliminate disasters. They provide for the restriction or suspension of citizens' rights and freedoms in order to achieve the general social interest, resolve the crisis and return to social regularity. Restrictions should be imposed to the necessary extent and applied without discrimination. Although decision-making power is usually concentrated in the executive, exceptional measures cannot abolish rights or affect democracy and the rule of law.

It constitutes an extraordinary law of necessity ${ }^{8}$, which may in some cases be guided substantially by international directorates, e.g., the IMF (economic adjustment

${ }^{4}$ A. Manesis (1980), Constitutional Law I. Sakkoulas, p. 137 (in Greek).

${ }^{5}$ D. Tsatsos (1994), Constitutional Law A': Theoretical Foundation. Sakkoulas, p. 177 (in Greek).

${ }^{6}$ A. Manitakis (2020), The Greek Constitutionalism 200 years after. Hellenic Open University, p. 101 (in Greek).

${ }^{7}$ B. Ackermann (2004), The Emergency Constitution. Yale Law Journal, 113, p. 1029.

${ }^{8} \mathrm{G}$. Gerapetritis (2012), The economic crisis as an element of deregulation of the hierarchy of sources of law: Legality or alibi?, Nomiko Vima, 60 p. 2754 (in Greek).

CONSTITUTIONAL LAW REVIEW 
programs and economic crisis) or the WHO (emergency measures and public health crisis), but under any circumstances can allow the abuse of power. It must be democratically legitimized through constitutional procedures and remain extraordinary, operating within an exceptional, crisis rule of law.

The resilience of the Greek Constitution has been highlighted during the recent crises that Greece faced: a) the economic crisis of 2010-2018, b) the refugee crisis of 2020, c) the current public health crisis $^{9}$. In all of these cases, Greece did not need to resort to a state of siege (Art. 48 of the Constitution). However, the other tools that are provided for were used in accordance with the constitutional requirements of the parliamentary regime. The concentration of power and the restriction of certain rights were temporary and careful aiming to protect the public interest. The law of necessity respected both the inalienable core of fundamental rights, as well as the temporary nature of the restrictions. Both the Greek justice system with the produced case law and the executive in each case tried to respond to the crisis without definitively crushing the constitutional framework and to restore regularity, when time was ripe, e.g., partial restoration of pensions, tax cuts, lifting of legal restrictions etc.

\section{The state of siege}

The state of siege as a state of exception is provided for in article 48 of the Constitution ${ }^{10}$. It refers to the suspension of force of certain articles of the Constitution under strict procedural and substantial conditions in case of war or national security. In this way, an exceptional circumstance is regulated by special rules, so that there are limits to the exercise of power and that the democratic nature of the republic is safeguarded. In pursuant to the constitutional provision, executive law 566/1977 was enacted, which has never been applied. Similar provisions can be found in article 15 (Derogation in time of emergency) of the European Convention of Human Rights (ECHR) and in article 4 of the International Covenant on Civil and Political Rights (ICCPR).

\subsection{History}

The concept of the state of siege, which is rooted in Roman Law and the principle salus publica suprema lex esto, was developed in Europe and the United States of America after World War $1^{11}$. A major influence was the work of Carl Schmitt about the state of exception in connection with the authority of the sovereign ${ }^{12}$. In Greece,

\footnotetext{
${ }^{9}$ E. Stylianidis (2020), Constitutional Revision of 2019: Missed Opportunity or new beginning?, Nomiki Vivliothiki (in Greek).

${ }^{10}$ S.-I. Koutnatzis (2017), Article 48, in F. Spyropoulos, X. Kontiadis, C. Anthopoulos, G. Gerapetritis (eds), The Constitution. Sakkoulas, p. 947 (in Greek).

${ }^{11} \mathrm{G}$. Agamben (2005), State of Exception, University of Chicago Press.

${ }^{12}$ C. Schmitt (1922), Politische Theologie: Vier Kapitel zur Lehre von der Souveränität, Duncker \& Humblot.
}

ARTICLES. ANALYSIS AND REFLECTIONS 


\section{Evripidis STYNIALIDIS}

it was first established in article 91 of the Constitution of 1911, according to which the executive law $\Delta \equiv \Theta / 1912$ was enacted. It was mainly applied in turbulent times leading to coups.

\subsection{Requirements}

In order for a state of siege to be declared it is required a case of: a) war, b) mobilization owing to external dangers or an imminent threat against national security, c) an armed coup aiming to overthrow the democratic regime. Moreover, a resolution should be adopted by a three-fifths majority of the total number of Parliament, upon a proposal of the Cabinet. If the Parliament is absent, a presidential decree is issued on the proposal of the Cabinet, which is submitted to Parliament for approval by a majority of the total number of members of Parliament as soon as its convocation is rendered possible and, in any case, no later than fifteen days.

\subsection{Consequences}

The Parliament, when a state of siege is declared, can suspend the force of the specific provisions of the Constitution. Specifically, the prohibition of individual administrative measures restrictive of the free movement or establishment in the country, and of the free exit and entrance therein (Art. 5 par. 4), the prohibition of arrest or imprisonment without a reasoned judicial warrant (Art. 6), the prohibition of establishment of extraordinary courts (Art. 8), the inviolability of private and family life (Art. 9), the right to assemble (Art. 11), the right to form associations (Art. 12 par. 1-4), the freedom of expression and of the press (Art. 14), the secrecy of letters and all other forms of free correspondence or communication (Art. 19), the prohibition of compulsory work (Art. 22 par. 4), the freedom to unionize and to strike (Art. 23), no jurisdiction of military, naval and air force courts over civilians (Art. 96 par. 4), and trial of felonies by mixed jury courts composed of ordinary judges and jurors (Art. 97).

The duration of the effect of the measures imposed cannot exceed fifteen days, which may be extended every fifteen days, only upon resolution passed by the Parliament. In addition, the resolution for declaring a state of siege is not subject to judicial review, because it is considered a Government Act, which is completely administered by the political authorities.

\section{The emergency mechanism of the Constitution}

The Constitution, besides the state of siege, also includes an emergency mechanism for crisis management, which enables fast-track legislation and allows for severe measures to be taken. It concerns extraordinary situations, such as natural and human disasters, as well as public health crises. 


\subsection{Procedural provisions}

This mechanism offers two main tools, which deviate from ordinary legislative procedure: a) the Acts of Legislative Content, and b) the very urgent bills. The use of those tools improves the reaction speed and thus the effectiveness, but also has the disadvantage of undermining the Parliament and the quality of legislation due to the lack of debate and consultation on the bill.

\subsubsection{Acts of Legislative Content}

The Acts of Legislative Content (ALCs), according to article 44 par. 1 of the Constitution, are issued under extraordinary circumstances of an urgent and unforeseeable need by way of derogation from the doctrine of separation of powers. The President of the Republic issues the ALCs upon the proposal of the Cabinet bypassing the Parliament. However, ALCs are subsequently submitted to Parliament for ratification within forty days of their issuance and are ratified within three months of their submission. Should such acts not be submitted to Parliament or not be ratified by Parliament in time, they henceforth cease to be in force.

\subsubsection{Very urgent bills}

Very urgent bills, which are provided for in article 76 par. 4 of the Constitution and article 109 of the Standing Orders of Parliament, serve a similar purpose. A Bill designated by the Government as very urgent can be introduced to Parliament to be voted upon in just one meeting. In this case, however, the Parliament precedes and does not follow the executive.

\subsection{Substantive provisions}

The Constitution allows for the restriction of fundamental rights under specific conditions, which is also subject to judicial review that offers protection to any person affected.

\subsubsection{General provision}

Fundamental rights may be restricted, as long as it is provided for either directly by the Constitution or by statute (Art. 25 par. 1 of the Constitution). Additionally, restrictions should also respect the principle of proportionality, which was introduced in the constitutional revision of 2001, though it had already been adopted by the Council of State (Symvoulio tis Epikrateias) (Decision No 2112/1984).

\subsubsection{Special provisions}

The special provisions in the Greek Constitution that allow for such limitations in fundamental rights are:

ARticles. AnALYSIS AND REFLECTIONS 


\section{Evripidis STYNIALIDIS}

a) Restriction of the free movement or establishment in the country, and of the free exit and entrance therein that is necessary for the protection of public health or the health of sick person (Art. 5 interpretive clause in conjunction with par. 4).

b) Requisition of property for the needs of the armed forces in case of war or mobilization, or for the purpose of facing an immediate social emergency that may endanger public order or health (Art. 18 par. 3).

c) Requisition of personal services in case of war or mobilization or to face defense needs of the country or urgent social emergencies resulting from disasters or liable to endanger public health (Art. 22 par. 4).

d) Appointment of personnel for a certain period of time in order to fill unforeseeable and urgent needs (Art. 103 par. 2).

Similarly, the ECHR explicitly provides for limitations in fundamental rights as long as they are prescribed by law and are necessary in a democratic society in the interests of national security, public safety or the economic well-being of the country, for the prevention of disorder or crime, for the protection of public order, health or morals, or for the protection of the rights and freedoms of others ${ }^{13}$. Specifically, these limitations refer to the prohibition of forced labor (Art. 4 par. 3c), the lawful detention of persons (Art. 5 par. 1e), the respect for private and family life (Art. 8 par. 2), the freedom of thought, conscience and religion (Art. 9 par. 2), the freedom of expression (Art. 10 par. 2), and the freedom of assembly and association (Art. 11 par. 2).

\subsection{Judicial review and parliamentary oversight}

A fundamental guarantee of the rule of law is that the measures imposed are subject to constitutional review, which in Greece is diffused. According to Art. 93 par. 4 of the Constitution, the courts are bound not to apply a statute whose content is contrary to the Constitution. This was first established in the Constitution of 1927 (Art. 5 interpretative statement), though the Court of Cassation (Areios Pagos) had already ruled against the application of a law as unconstitutional (Decision No 23/1897).

The fulfillment of the conditions of Art. 44 par. 1 of the Constitution, that is whether there is indeed an urgent and unforeseeable need, is not subject to judicial review, because the assessment of the need to issue ALCs falls within the Parliament, which according to the Constitution, exercises the legislative authority (Decisions No $1250 / 2003,3636 / 1989,2289 / 1987$ of the Council of State). However, the court may review whether the procedural requirements were met, that is their timely submission to Parliament in accordance with the Constitution (Art. 44 par. 1 in conjunction with Art. 72 par. 1 of the Constitution), as well as their content in terms of constitutionality.

${ }^{13}$ A. Sisislianos (2021), The execution of the decisions of the ECtHR by Greece. Nomiki Vivliothiki (in Greek).

CONSTITUTIONAL LAW REVIEW 


\section{Lessons from recent experience}

The first application of an extraordinary law of necessity, during the last decade, was because of the largest financial crisis that struck Greece after World War II. Greece faced the dilemma of a disorderly default or a sudden adjustment of the economy. The second option was chosen and as a result the resilience of the Constitution, the functioning of the Parliament and the quality of legislation, the protection of fundamental rights, the survival of the welfare state, and ultimately the survival and dignity of the people and of the most historic Republic in the world were put to the test ${ }^{14}$.

Notably, while in 2008 there were 102 statutes issued and only 1 ALC, in 201267 statutes and 28 ALCs were issued. Among those 67 statutes, 11 were ratifications of ALCs, 21 were ratifications or amendments of international treaties and directives, 2 concerned the medium-term budgetary framework (MTBF) and its implementation, 3 concerned the economic adjustment programs and their implementation and only 30 concerned other issues. Besides, most of them were introduced to Parliament as very urgent bills.

This abnormal legislative procedure clearly damaged the quality of legislation and the functioning of the Parliament. Due to the circumstances, the role of an international directorate, the so-called troika, was strengthened and an extraordinary law of necessity was established. However, the Constitution withstood and the legislative, executive and judicial authorities gradually restored regularity safeguarding, despite some losses, the welfare state and the fundamental rights.

\section{The COVID-19 pandemic}

The SARS-CoV-2 coronavirus that causes COVID-19 first appeared in China in December 2019 and started affecting Europe in February 2020. On 30 January 2020, the World Health Organization (WHO) announced that the outbreak constitutes a Public Health Emergency of International Concern (PHEIC) and on 11 March 2020 declared the situation as a pandemic signaling the beginning of the global crisis. In Greece, the first case was recorded on 26 February 2020. The Government immediately adopted emergency measures, which severely affected every aspect of social and economic life.

\subsection{Procedural aspect of the measures}

The need for a prompt response dictated the use of ALCs. The ALCs were issued under strict conditions and were subsequently specified through Ministerial Decisions, which were renewed every few weeks. Particularly, while in 2019 there were only

${ }^{14}$ P. Pavlopoulos (2014), Public Law in the Constellation of the Economic Crisis. Livanis (in Greek); P. Pavlopoulos (2010), The Revision of the Constitution. Livanis (in Greek).

ARTICLES. ANALYSIS AND REFLECTIONS 


\section{Evripidis STYNIALIDIS}

5 ALCs adopted, in 202012 ALCs were adopted. Among those 12 ALCs, 9 concerned measures against COVID-19.

The ALCs were ratified by Parliament in accordance with the requirements of the Constitution. In order to continue its operation, the Parliament reformed its Standing Orders allowing its meetings to be held online and voting to take place remotely. In contrast, the Government did not declare a state of siege, which is not provided for on public health grounds and would require an extremely broad interpretation of the Art. 48 of the Constitution.

\subsection{Substantive aspect of the measures}

The measures imposed aimed at the prevention and containment of COVID-19, the surveillance of public health, as well as to alleviate the consequences of the pandemic ${ }^{15}$. Depending on the intensity of the pandemic there were: a) general restrictions at the national level, b) local restrictions in certain areas, and c) special restrictions on particular population groups. Further, the measures had limited duration with possibility of extension, given that fundamental rights were only temporary restricted and were not suspended. Besides, they were in line with the recommendations of the WHO and of the relevant European authorities.

\subsubsection{General measures}

General measures focused on social distancing and included restrictions on the freedom of movement of citizens and the obligation to wear masks in public places, restrictions on the operation or even closure of schools, universities, retail shops, restaurants, theaters, cinemas, venues for sporting and artistic events, places of worship, the suspension of courts of justice and prosecution offices, and the imposition of quarantine on travelers entering Greece.

\subsubsection{Financial support}

The pandemic and the subsequent measures caused a serious disruption to national economy. The government, in accordance with article 106 par. 1 of the Constitution, introduced measures, such as the suspension of tax liabilities, the extension for payment of insurance contributions, as well as the payment of compensation to businesses and to employees of businesses whose operation has been suspended, as well as to self-employed and to unemployed persons.

\subsubsection{Requisitions of property and of personal services}

The need to reinforce the public healthcare system urged the government to proceed, in accordance with articles 18 par. 3 and 22 par. 4 of the Constitution, to the

\footnotetext{
${ }^{15} \mathrm{~V}$. Tzemos (2020), Day to night: The pandemic, life as the ultimate good and the two aspects of proportionality, Public Law 5(1-2), p. 1 (in Greek).
}

CONSTITUTIONAL LAW REVIEW 
The state of exception in the Greek Constitution...

requisition of private healthcare facilities, wards, beds and intensive care units, as well as of personal medical services. In addition, it requisitioned tourist accommodation for those diagnosed with COVID-19 during vacation.

\subsubsection{Compulsory testing and vaccination}

Following the development of vaccines against COVID-19, the government launched a vaccination campaign and also adopted:

- Compulsory preventive testing and employers' right to request information on whether or not employees have been vaccinated.

- Compulsory vaccination of employees serving to the Special Disaster Response Units (EMAK) due to the particular working conditions and the need to ensure uninterrupted operation. Otherwise, they are replaced by other employees of the Fire Service who are vaccinated.

- Compulsory vaccination of all employees of care facilities for the elderly and disabled persons, as well as of healthcare facilities. In case of failure to comply with this obligation, public sector employees are suspended without pay. In any other case, the employer is not obliged to accept the employee's labor and is exempted from the obligation to pay remuneration (Art. 206 par. 1 and 2 of Law 4820/2021, as amended by Art. 36 of Law 4829/2021).

- Obligation of primary and secondary school teachers to present a vaccination certificate or a negative diagnostic test. Otherwise, they are not allowed to enter the school units and are suspended without pay (Art. 111 par. 8 of Law 4821/2021).

\subsection{Constitutional foundation}

The basic feature of the COVID-19 pandemic is that it highlighted the importance of personal responsibility of the citizen as an individual and as a member of society. The exercise of the fundamental right to life and to self-determination in regards to vaccination crossed for the first time the rights of others due to the contagiousness of the virus and the protection of public health.

However, the limitations were temporary and affected exclusively those fundamental rights provided for in the Constitution that were linked to the management of the pandemic. Specifically, they concerned the right to free development of personality and to participation in the social, economic and political life of the country (Art. 5 par. 1), the free movement or establishment in the country (Art. 5 par. 4), the right to protection of health (Art. 5 par. 5 and Art. 21 par. 3), the right to respect for private and family life (Art. 9), the right to be protected from the collection, processing and use of personal data (Art. 9A), the right to assemble (Art. 11), the freedom of religious worship (Art. 13 par. 2), the right to education (Art. 16 par. 1),

Articles. AnALysis and Reflections 


\section{Evripidis STYNIALIDIS}

the right to protection of property (Art 17 par. 1), the right to legal protection (Art. 20 par. 1), and the right to work (Art. 22 par. 1).

\subsection{Judicial review}

The proportionality of the measures imposed is reviewed, that is the necessity, suitability, as well as the intensity and duration of the restrictive measures ${ }^{16}$, and also the equality in the sense of non-discrimination between vaccinated and non-vaccinated individuals. So far, the Council of State has found all measures to be constitutional:

- Prohibition of performing any kind of services and rituals in places of religious worship (Decisions No 49/2020, 60/2020, 99/2020 of the Suspension Commission).

- Prohibition of public outdoor assemblies in which four or more people participate (Decisions No 262-263/2020).

- Compulsory vaccination of employees serving in the Special Disaster Response Units (EMAK) (Decision No 133/2021 of the Suspension Commission).

- Compulsory COVID-19 self-testing for students and teachers of primary and secondary schools (Decision No 135/2021 of the Suspension Commission).

- Compulsory vaccination of health workers (Decisions No 250-252/2021 of the Suspension Commission). Vaccination is required to protect public health from the spread of the coronavirus to hospital staff, who is a particularly vulnerable group, and to ensure that the proper operation of hospitals would not be disrupted if a member of the staff were to contract coronavirus.

- Compulsory self-testing COVID-19 for public sector employees and the electronic recording of its result (Decision No 1386/2021 of the Suspension Commission).

\section{Conclusion}

The endangerment of life and health on global level confirmed the saying of Socrates "I know that I know nothing" and the "the awareness of ignorance", as Jürgen Habermas accurately pointed out in an interview with Le Monde newspaper ${ }^{17}$. Nevertheless, the Greek Constitution withstood and responded to the public health crisis effectively in accordance with democracy and the rule of law.

The individualistic concept of fundamental rights proved to be insufficient. Conversely, the pandemic tragically reminded us that fundamental rights entail individual and

${ }^{16}$ C. Akrivopoulou (2006), The horizontal effect of constitutional rights and their judicial protection. Human Rights 30, p. 483 (in Greek); C. Anthopoulos (2017), Article 25, in F. Spyropoulos, X. Kontiadis, C. Anthopoulos, G. Gerapetritis (eds), The Constitution. Sakkoulas, p. 684 (in Greek).

${ }^{17}$ J. Jürgen Habermas, Interview with Le Monde newspaper on 10 April 2020 (in French). 
The state of exception in the Greek Constitution...

social responsibilities. They can only be realized in the context of society and of an organized and orderly republic ${ }^{18}$.

The relation between law and morality was updated. Life and health have emerged not just as fundamental rights, but as constitutional values as well. Restrictive measures, which were inconceivable in Greece and in Europe for constitutional law theory, have become through balancing necessary tools for sustaining life, biological existence, and coexistence with other people in society.

The pandemic leads to a reflection and urges to pursue individual freedom within anthropocentrism and with personal responsibility and solidarity to others. The conflict between freedom and justice that some seek to provoke putting forward false dilemmas in favor of individual freedom against justice, safety and public health, are misguided, populist and irrational.

The answer was given by Albert Camus in a letter sent to Charles De Gaulle in 1943 referring to the ethical values of justice and freedom: "Justice and freedom cannot be mutually exclusive and are still essential for rebuilding the world and opposing the destructive logics of history"19.

\footnotetext{
${ }^{18}$ T. Iliopoulou-Stragga (2018), General theory of fundamental rights: Aspects of multilevel protection in the European area. Sakkoulas (in Greek).

${ }^{19}$ V. Duclert (2020), Camus, des pays de liberté. Stock.
} 